KAIROS ELT JOURNAL, Vol. 1, No. 3, December 2017

Copyright $\odot 2017$, ISSN: 2580-4278

\title{
THE USE THINK PAIR SHARE TO IMPROVE STUDENTS' READING COMPREHENSION AT THE NINTH GRADE STUDENTS OF JUNIOR HIGH SCHOOL ERA IBANG MEDAN
}

\author{
Evi Kristin Mahdalena, Rosa Maria Simamora, Fiber Yun A Ginting \\ Catholic University of Saint Thomas
}

\begin{abstract}
This research is conducted in order to improve students' reading comprehension in the easiest way through using think pair share of the ninth grade students of Junior High School Era Ibang Medan, and it also help the English teacher of the ninth grade students of Junior High School Era Ibang Medan to managed activities in classroom.In conducting this research, the researcher used Classroom Action Research (CAR) as the method of research. This research consisted of two cycles and each cycle consisted of four steps, they were planning, action, observation and reflecting. Each cycle was conducted in three meetings, so the researcher conducted this researcher in six meetings for one month and two weeks. The data were in the form of qualitative and quantitative data. The qualitative data was analyze the learning teaching process. The quantitative data was to count the students' score in pre-test and post-test.The result of this research shows that using think pair share of the ninth grade students of Junior High School Era Ibang Medan could improve their reading skills. The students' responses showed that they were interested in learning reading through think pair share. Morever, the students' achievements in pre-test and post-test showed a significant improvement. The students' average score in pre-test was $53,19 \%$, while in the formative test in cycle I, the students' average score is 60,03, and in the post-test cycle II, the students' average score is 76 . That means the think pair share can improve the students' reading skill.
\end{abstract}

Key words: reading comprehension, think pair share

\section{INTRODUCTION}

Most people around the world use English as communication. In learning English language, there are four skills should be taught to students. They are listening, speaking, reading and writing. Among those four skills, reading is one of the four language components that should be mastered by students.

Moreover, teaching reading for students is very important. The reason for teaching reading to the students is because it belongs to the basic language skills in English, just as important as speaking, listening, and writing. Beside, reading is closely related with other subject. Most of the materials gave by the teacher (in English or other subject) are presented in written form, for example in handbook, handout, etc. It can be concluded that to understand the materials, the students must have the ability to look at and get the meaning of written text.

Reading is one of the four language skills that learner needs to master in order to ensure success in learning. Broughton (2003:90) states that reading is essentially an intellectual skill this is the ability to correlate the black marks on the paper by way of the formal elements of language, they can say the words as sound, with meanings which those words symbolize. It was pointed out that reading involved correlating elements of language with meaning. The familiar off all elements of language are ,words ${ }^{\text {ee }}$ and it must be quiet clear that part involved in understanding a text is understanding the meaning of individual words in that text. Reading is about understanding written texts. It is a complex activity that involves both perception and thought. 
Grabe and Stoller (2002:09) state that reading is the ability to draw meaning from printed page and interpret this information appropriately. It means comprehending and interpreting the information of the text are important. It implies that students need to learn a considerable amount of information from a text. By learning reading, they are able to learn more about language component like grammar and vocabulary, which are absolutely needed to master in learning language. It shows that if the students ${ }^{\text {ee }}$ reading skill is poor, they also will be less in reaching their ability in mastering other English skills. Purposes of reading are getting general information from the text, getting specific information from the text and for pleasure or for interest.

There are several technique in learning, one of them is think pair share. Think pair share technique is a technique introduced by Frank Lyman. This is a cooperative learning technique where students think about their response to a prompt or question, then discuss their individual answers in pairs. This is a low risk technique to get many students actively involved in classes of any size. Using this technique, all of the students can be involved in the learning process effectively. Researcher believes that think pair share teaching technique can improve students' reading comprehension effectively. To get a good achievement for English subject, students are taught to think individually and discuss the ideas with their partner and then share the result of discussion in the classroom.

Based on the researcher's observations, students of Junior High School Era Ibang Medan have many difficulties in reading comprehension. Because each students have different background knowledge. For example, they have difficulties in understanding and finding the main idea in a text. They know how to pronounce the word but not really understand the meaning of the sentence is read. Therefore, teachers must have appropriate learning strategies to help students' in reading comprehension. The technique used should increase students' interest in reading to avoid boredom. So that students can easy to understand in reading comprehension. In order to solve that problem, a good technique, method, or technique should be used in order to make students become active, enjoy, interest and comprehend about the main point of the reading text. In this case the author use the Think-Pair-Share Technique to improving students' reading comprehension especially students of Junior High School Era Ibang Medan.

Based on the observation, the researchers wants to conduct a research to know how far the ability of the ninth grade students of Junior High School Era Ibang Medan after they are taught using reading comprehension through think pair share teaching technique. Hence, the researcher conducted an action research focusing on reading ability of narrative text using think pair share for nineth grade students of Junior High School Era Ibang Medan in Academic Year $2016 / 2017$.

\section{REVIEW OF LITERATURE Reading}

According to Wahyuni (2014), reading is as a selective process taking place between the reader text, in which background knowledge and various type of language knowledge interact with information in text to contribute to text the comprehension. The understanding of reading comes from the interaction between the words that are written and how they get the knowledge outside the text. Anderson (in Nunan, 2003:68) states that: reading is a fluent process of readers combining information from a text and their own background knowledge to build meaning.

As the conclusion, reading is a complex process of thinking in assigning meaning from printed materials which involve most of the reader's intell lectual act such as pronounciation and comprehension in order to receive ideas or information extended by the text. It can be seen 
KAIROS ELT JOURNAL, Vol. 1, No. 3, December 2017

Copyright $\odot 2017$, ISSN: 2580-4278

that reading is not only looking at word or line to line to understand what is being read. It means that reading is a process to understand the text context and to get information.

\section{The Purpose of Reading}

According to Grabe and Stoller (2002:11-15) the purpose of reading are classified into:

1) Reading to search for simple information

Reading to search for simple information is a common reading ability though some researches see it as relatively independently cognitive process. It is used so often in reading tasks that it is probably best seen as a type of reading ability. Similary, reading to skim is a common part of many reading task and a useful skill in its own right. It involves, in essence, a combination of strategies for guessing where important information might be in the test using basic reading comprehension skills on those segments of the text until a general idea is formed.

2) Reading to learn from text

Reading to learn typically occurs in academic and professional contexts in which a person needs to learn a considerable amount of information of a text.

3) Reading to integrate information, write and critique text

Reading to integrate information requires additional decisions about the relatively importance of complementary, mutually supporting or conflicting information and the likely restructuring of rhetorical frame to accommodate information from multiple sources. Both reading to write and reading to critique text require abilities to compose, select and critique information from the text.

4) Reading for general comprehension

Reading for general comprehension is the most basic purpose for reading, underlying and supporting most other purpose for reading. General reading comprehension is actually more complex the commonly assumed. Reading for general comprehension requires very rapid automatic processing of words, strong skill in forming a general meaning representation of main ideas and efficient coordination of many processes under very limited time constraints.

\section{Reading Comprehension}

The first point to be made about the reading process is reading comprehension. Reading comprehension is the most obvious sense. According to Grabe and Stoller (2002:17) reading comprehension needs the ability to understand or to gain the information from the text.

Reading comprehension involves taking meaning from a text in order to obtain meaning from text. Someone could be said to comprehend a text fully when he can:(1) recognize the words and the sentences of the text and know what those words and sentence mean, (2) associate meanings, both denotative and connotative, from personal experiences with the printed text, (3) recognize how all the meaning and or they fit together contextually, and (4) make value judgements and based on the reading experiences.

From the explanation above, it can be conclude that, in reading comprehension, a reader must have available ability in the process of interpreting the text appropriately in comprehending text.

\section{Types of Narrative Text}

Narrative text is a text which contains about a story in the past, and it may be a fiction or non fiction story. The purpose of this text is actually to entertain the reader. (Sugiarto, 2014:207).

Neo (2005:8) states that there can be a combination of narratives within each of this different types. Sometimes, the term genre is used for the type of narrative, the notion of genre is to help generate story ideas. Here are some examples of the different types of narrative showing typical features: 
a) Humor

A humorous narrative is one of that aims to make audience laugh as a part of telling story. Here is typical structure:

a. Orientation $\quad:$ the narrator tells the funny characters names in unusual setting

b. Complication : in this part, something crazy happen.

c. Sequence of event : there are many imaginative ideas here funny things said by characters and extraordinary things happening to ordinary people.

d. Resolution : All's well that end well.

b) Romance

The romance narrative typically tells of two lovers who overcome difficulties to end up together. Here are the usual features:

a. Orientation : it contains hunk male and female who is looking for love, exotic setting, sun set, beaches, and moonlight.

b. Complication : boy meets girl.

c. Sequence of event : it contains the development relationship, jealously, love, hurt, pian, warm, sharing, and overcoming problems.

d. Resolution : boy gets girl, marry and live happy ever after.

c) Historical Feature

Here are the feature of a typical historical fiction text:

a. Orientation $\quad$ : a setting in the past and description of a period in history.

b. Complication : good meets evil

c. Sequence of event : action related to a period in history, character's lives a affected by the events of history, description of live at the time.

d. Resolution : characters survive the chaos of the time (for example, the war ends).

d) The Diary Novel

This type of narrative as the text presented like diary entries. Here are the features of a typical diary- novel:

a. Orientation : main character is the narrator. Time setting is given by diary entries.

b. Complication : given one of diary entries. It can be related to romance, adventure, humor, mystery, or other type.

c. Sequence of event : diary entries tell of feelings, hopes, and happening.

d. Reorientation : the narrator tells what happens to solve the complication.

e) Fantasy

Below are the features of a typical fantasy narrative:

a. Orientation : setting may be in another dimension with goals, witches, wizard, and so son. Hero who may has magical power.

b. Complication : evil forces affect the goodies.

c. Sequence of event : use of magic. Action includes elves, dragons ans mystical beasts, heroism.

d. Resolution : God defeats evil forces.

f) Science Fiction

Science fiction narratives the setting involving science and technology.

Here are the typical features of the text type:

a. Orientation $\quad:$ a feature setting and a world with technology. 

b. Complication
: an evil force threatens the world.
c. Sequence of event : imaginative description. Action involves technology, science, and super invention.
d. Resolution
: good defeats evil.
e. Coda
: take care that science is used for good, not evil.

\section{Think Pair Share}

Cooperative learning is the one of most researched teaching models. It is a learning model which did not evolve from one individual ${ }^{e} \mathrm{~s}$ theory or from a single approach to learning. Arends (2007:351) states that most developers of cooperative learning in heterogeneous group is beneficial for all students with lesser abilitites learn more by working alongside those whi have gather abilities and that latter benefit from the process of serving as tutors to their lessable peers. Jolliffe $(2007: 14)$ states that cooperative learning structures create a situation in which the only way group members can complete the task is if the whole group does. Think Pair Share is a cooperative learning discussion strategy first developed by Professor Frank Lyman at University of Maryland in 1981 and adopted by many writers in the field of cooperative learning since then. In addition, Kagan (2009:14) also state that Frank Lyman created a very powerfull frame sequencing three structures called Think-pair-Share. Since there are many ways to think, many ways to pair up, and many ways to share with the class. ThinkPair-Share is a cooperative learning strategy where students think about their response to a prompt or question, then discuss their individual answers in pairs.

Ledlow (2001:1) states Think Pair Share is a low-risk strategy to get many students actively involved in classes of any size. The procedure is simple: after asking question, the teacher tells students to think silently about their answer. As a variation, you might have them write their individual answer. Then the teacher asks them to work in pair to compare or discuss their responses. Finally, the teacher call randomly on a few students to summarize their discussion or give their answer. The random calls are important to ensure that students are individually accountable for participating. Use of this strategy will help students to; draw on background knowledge to understand ideas, gives students time to think, generate and analyze ideas, maintain a high level of engagement, participate in small-group interactions, synthesize information, develop and practice reading skills. Use of this strategy also helps teachers increase their wait time, thus increasing student think time, as well.

\section{Teaching Reading Through Think Pair Share}

As what has been mentioned before, the application of this strategy in teaching learning

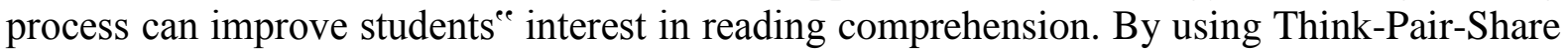
technique, researchers will make the students learn more fun, active and not bored. Arrends (2007:35) states that think pair share strategy has grown out of the cooperative learning and wait-time research. Arrends (2009:354) states that there were three steps in teaching reading using think-pair-share, as follows:

Step 1 Thinking: The teacher poses a question or an issue associated with the lesson and asks students to spend a minute thinking alone about the answer or the issue. Students need to be taught that talking is not part of thinking time.

Step 2 Pairing: Next, the teacher asks students to pair off and discuss what they have been thinking about. Interaction during this period can be sharing answers if a question has been posed or sharing ideas if a specific issue was identified. Usually, teacher sallow no more than four or five minutes for pairing.

Step 3 Sharing: In the final step, the teacher asks the pairs to share what they have been talking about with the whole class. It is effective to simply go around the room from pair to pair continue until about a fourth or a half of the pairs have had a chance to report.

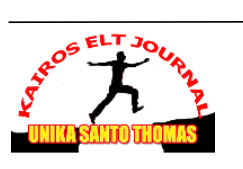


Therefore, by using think-pair-share the students can improve the quality of their responses. So that, students are actively engaged in think, thinking becomes more focused when it is discussed with a partner and to building on the other ideas is an important skill for students to learn. In addition, by using think-pair-share in teaching learning process in reading comprehension will be make the students easier to answer question about the reading text.

\section{The advantages and disadvantages of Using Think Pair Share}

According to Fauziyati (2013:42) there are some advantages and disadvantages they are as follows:

1) The Think-Pair-Share technique is quick and does not take much preparation time.

2) The Think-Pair-Share technique makes classroom discussion more productive, as students have already had an opportunity to think about their ideas before sharing with the whole class.

3) Students have opportunity to learn higher-level thinking skills from their peers, and gain self confidence when reporting ideas to the whole class.

4) Students are able to rehearse responses mentally and verbally, and all students have an opportunity to talk.

5) Both students and teacher have increased opportunities to think and become involved in group discussion.

6) The Think-Pair-Share technique is applicable across all grade levels and class sizes.

In spite of the advantages, the Think-Pair-Share technique also has some disadvantages, they are as follows:

1) Not all students focus on the topic (questions) given, because they can share everything with their partner out of the topic (questions) given.

2) There is a possibility that the students who have low understanding about the topic (the questions) given likely cheat to other pairs.

\section{RESEARCH METHOD}

The research design used in this study is Classroom Action Research (CAR). Metteal (2001:6-13) states that Clasroom Action Research (CAR) is a method of finding out what works best in classroom so that we can improve student learning. The goal of Classroom Action Research (CAR) is to improve your own teaching in your own classroom.

According to Koshy (2010:1) Action research is a method used for improving educational practice. It involves action, evaluation and reflection and, based on gathered evidence, changes in practice are implemented. Based on explanation above, it is conclude that action reserach is identify a process teaching learning, do something resolve the problem.

The writer will conduct the research in four phases: planning, action, observation, and reflection. This study will be conducted in two cycles. The cyclical can be seen in this below figure based on the Kemmis and Mc. Taggart in Burns (2010).

\section{DATA ANALYSIS}

\section{The Quantitative and Qualitative Data}

The quantitative data were taken from the table. This research explains from the beginning to the end of the research at the school, and the observation sheet, diary notes and documentation. 
KAIROS ELT JOURNAL, Vol. 1, No. 3, December 2017

Copyright@2017, ISSN: 2580-4278

\section{The Diary Notes}

Meeting 1: Pre-test, Wednesday, $2^{\text {th }}$ October 2016, 09.45-11.05

At the first meeting, the researcher entered the classroom, the researcher greeted the students, introduced herself, and told the purpose of her coming. When the researcher came to the class, the class was condusive at the beginning. They looked so amazed. In their thought who this girl, what she want gonna did. The researcher told the students to do the test (pretest) before the treatment was conducted for next meeting. This test consists of 20 items in multiple choice and carried out in 45 minutes. They did the test in 60 minutes and the result of students' score were taken from table.

Table 4.1. Data Frequency Distribution for Score of Pre-test

\begin{tabular}{|l|l|l|l|l|}
\hline No & $\begin{array}{l}\text { Score } \\
\text { Interval }\end{array}$ & Frequency & Percentage & Category \\
\hline 1 & $85-100$ & 0 student & $0 \%$ & Very High \\
\hline 2 & $70-84$ & 4 student & $15,38 \%$ & High \\
\hline 3 & $60-69$ & 6 student & $23,07 \%$ & Average \\
\hline 4 & $50-59$ & 7 student & $26,92 \%$ & Low \\
\hline 5 & $0-49$ & 9 student & $34,89 \%$ & Very Low \\
\hline Total & 26 students & $100 \%$ & \\
\hline Mean & & 53,19 & \\
\hline
\end{tabular}

The quantitative data were taken from the results of pre-test, formative cycle 1 , and pos-test cycle 2. Before conducting the first cycle, the pre-test was given to measure the improvement of the students' reading comprehension. Based on, the table score pre-test was given, the measure improvement of the students was score 85-100 score, no one students got very high score. $70-84$ scores were $15,38 \%$ got by 4 students as the high scores, 60-69 scores were $23,07 \%$ as the average points got by 6 students, $50-59$ scores were $26,92 \%$ as the low scores got by 7 students, and 0-49 scores were $34,89 \%$ got by 9 students as the lowest scores. In the end meeting of cycle 1, the formative was given to measure the improvement of the students. From the result of the pre-test, there were 2 students 26 students who passed the Minimum Mastery Criterion ( Kriteria Kelulusan Minimal/KKM).

\section{Cycle I}

\section{Meeting 2: Cycle 1, Saturday, October 29 ${ }^{\text {th }}, 2016,09,35-10-15$}

The second meeting the researcher greeted the students before start the lesson and checked the attendance, but while checked the attendance, there were 3 students absent because was sick. After checked the attendance the researcher announced their test there were 2 students passed. So, the researcher gave them motivation for them did not passed the test they could did the next test. In the second meeting was the beginning of cycle I, it means that the researcher started the treatment teaching reading comprehension by using think pair share technique. The researcher asked them to apply the technique on the test after the researcher explained about narrative text and how to find the main idea. and gave the examples of think pair share.

\section{Meeting 3, Monday, October 31th, 2016, 08,00-09,20}

In the third meeting, the writer applied think pair share into 5 groups. The researcher shared them into 5 groups, each groups consisted of 5 to 6 students and asked a student to share 5 texts. They did the treatment like the researcher had told. After that they discussed in their groups and they discuss and learn each other and share with each other in their groups what they understanding in that text. When they reading the text some students in groups ask how to pronounce the words in that text. And then the researcher ask the students to gave attention

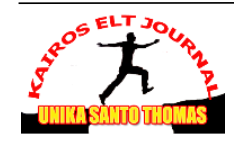


what the researcher explained and they gave they attention. After they knew how to pronounce that words the researcher asked them to continued they discussion. When they discussed the text, the condition of class became noisy because they share each other. They looked serious and enjoyed when they discussed with their partner in groups. The researcher gave time in their discussion 50 minutes. When the 50 minutes passed. The researcher asked them to presented what they had been discussed with their friend in front of the class. Before timing had finished 10 minutes more the researcher concluded the material that had discussed.

\section{Meeting 4, Wednesday, November 02th, 2016, 09,45- 11,05}

In the fourth meeting, the researcher did the formative test after giving the treatment. The writer wanted to know if the students' reading comprehension better after giving the treatment. The researcher explained the topic before doing the test. The researcher gave the items on test. The researcher gave the items on pre-test consisting of 25 items to improve their scores in the test and showed their achievements' reading comprehension. They asked the researcher why they did the test again so the researcher explained them the purpose of it. They did the test individually, but there were some students look did not confident with their answer so they cheated the answer of their friends, The researcher asked them to open their dictionaries to find the meanings. Time was up and the researcher left the classroom. The result of the formative cycle I was better than the score in the pre-test.

Table 4.2. Data Frequency Distribution for Score of Formative Test Cycle I

\begin{tabular}{|l|l|l|l|l|}
\hline No & $\begin{array}{l}\text { Score } \\
\text { Interval }\end{array}$ & Frequency & Percentage & Category \\
\hline 1 & $85-100$ & 0 student & $0 \%$ & Very High \\
\hline 2 & $70-84$ & 5 students & $19,23 \%$ & High \\
\hline 3 & $60-69$ & 8 students & $30,76 \%$ & Average \\
\hline 4 & $50-59$ & 10 students & $38,46 \%$ & Low \\
\hline 5 & $0-49$ & 3 students & $11,53 \%$ & Very Low \\
\hline Total & 26 students & $100 \%$ & \\
\hline Mean & & 60 & \\
\hline
\end{tabular}

Based on the table score of formative was given measure the improvement of the students was 85-100 score, no one students got very high score. $70-84$ scores were 19,23\% got by 5 students as the high scores, 60-69 scores were 30,76\% as the average points got by 8 students, 50-59 scores were 38,46\% as the low scores got by 10 students, and 0-49 scores were $11,53 \%$ got by 3 students as the lowest scores. Then, at the end at meeting of cycle 2, the postest was given to measure the students' improvement after the treatment. From the result of formative test, it was found there were 4 students from 26 students who passed KKM.

\section{Cycle 2}

\section{Meeting 5, Cycle 2, Saturday, November $05^{\text {th }}, 2016$}

In the fifth meeting, the researcher did cycle 2 to show the students' improvement. The writer explained about think pair share. The researcher explained about think pair share and gave them motivation, the students look spirit to follow English subject and the students listen the researcher about the topic and asked questions how far they know about think pair share after they learnt in cycle 1 . And then the researcher choosen 1 students to explained how far they know about think pair share. But when the researcher asked him to explained in the front of class, he told me in my seat miss please, I asked him once again but he still said the same. I asked him once again did not afraid, finally he came to front and explained a little what he knew about think pair share. In cycle 2, they focused on writer's explanation and made

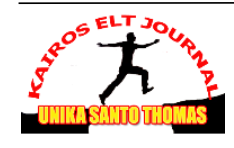


KAIROS ELT JOURNAL, Vol. 1, No. 3, December 2017

Copyright@2017, ISSN: 2580-4278

condusive class. The researcher shared students into 5 groups so they can learn with their friend and share about the material. While they were discussed the class condition was more relax and comfortable. Although there were some sounds heard but the class could be controlled.

\section{Meeting 6, Monday, November $07^{\text {th }}, 2016$}

In the last meeting, the researcher greeted the students, after doing the last test, the researcher explained again about narrative text and how to found the main idea. The students looked seriously. The researcher shared the test to them. They did the test individually and they did the test seriously. They can use dictionaries to find the meanings. If they did know the meaning in that text. So, it can help them to finished the test. The last test consisted 20 items to seen if their reading comprehension in narrative text was improved.

In this meeting, the students made better improvement than that in previous meeting. After calculating their score tests, it was founded that there were 22 students of 26 students who passed the KKM and 4 students could not pass the KKM. It can be said that think pair share can improve their reading comprehension which shown below:

Table 4.3. Data Frequency Distribution for Score of Post-Test Cycle II

\begin{tabular}{|l|l|l|l|l|}
\hline No & $\begin{array}{l}\text { Score } \\
\text { interval }\end{array}$ & Frequency & Percentage & Category \\
\hline 1 & $85-100$ & 3 students & $11,53 \%$ & Very High \\
\hline 2 & $70-84$ & 18 students & $69,23 \%$ & High \\
\hline 3 & $60-69$ & 2 students & $7,69 \%$ & Average \\
\hline 4 & $50-59$ & 1 students & $3,84 \%$ & Low \\
\hline 5 & $0-49$ & 2 students & $7,69 \%$ & Very Low \\
\hline Total & 26 students & $100 \%$ & \\
\hline Mean & & 76 & \\
\hline
\end{tabular}

Based on the table above score of pre-test was give measure the improvement of the students with percentage $85-100$ score, 3 students got very high score was $11,53 \%, 70-84$ scores were $69,23 \%$ got by 18 students as the high scores, $60-69$ scores were $22,22 \%$ as the average points got by 2 students, $50-59$ scores were 3,84\% as the low scores got by 2 students, and 0-49 scores were 7,69\% got by 1 students as the lowest scores. at the end meeting cycle 2 the post-test was given to measure the students' improvement after treatment. From the result of post-test cycle 2. It was found that 21 students passed the Minimum Mastery Criterion (Kriteria Kelulusan Minimal/KKM) with 75 score. So, the result of the table from post-test cycle 2 shows with the score 75, that the students' score more increase than in pre-test. The think pair share can improve the students' reading comprehension on narrative text.

To find out the students' mean score in each test, the writer applied the following formula: $\mathbf{X}=\frac{\sum x}{N} \mathbf{x} 100 \%$

So, from the formula above, the results of the students' mean score was shown as follows:

a. In the pre-test, the total score of the students was

$\frac{1383}{26}=53,19$

b. In the formative cycle I, the total score of the students was

$\frac{1561}{26}=60,03$

c. In the post test cycle II, the total score of the students was

$\frac{1976}{26}=76$

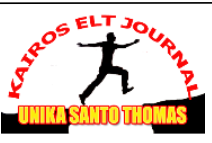


KAIROS ELT JOURNAL, Vol. 1, No. 3, December 2017

Copyright@ 02017 , ISSN: 2580-4278

By observing the improvement reading skills as written in the table above, the writer concluded that think pair share could improve their reading skills. It could be seen from the score from pre-test up to post-test cycle II. In pre-test the students' mean score was 53,19, while the students' mean score in formative cycle I was 60,03 , so the increasing point was 6,84 , and in post-test cycle II, the mean of the students' score was 76. So, the increasing point from pretest to cycle II was 15,97 .

Next, after calculating the mean of the students' score, the writer calculated it in the form of percentage to know the total of the students who passed the KKM. The writer used the following formula:

$\mathbf{P}=\frac{R}{T} x \mathbf{1 0 0 \%}$

The total number of students who passed the KKM could be seen as follow:

a. In the pre-test, the total number of students who passed the KKM was

$\frac{2}{26} \times 100 \%=7,69 \%$

b. In the formative cycle I, the total number of students who passed the KKM was

$\frac{4}{26} \times 100 \%=15,38 \%$

c. In the post-test cycle II, the total number of students who passed the KKM was

$\frac{21}{26} \times 100 \%=80,76 \%$

So, from the percentage above, it could be concluded that the percentage of students who passed the KKM was increased from pre-test up to cycle II. In pre-test, the total of the students who passed the KKM was 2 students, it was 7,69\%. In formative cycle I, the total of the students who passed the KKM was 4 students, it was 15,38\%, so the difference was 7,69\%, and in the post-test cycle II, the total number of students who passed the KKM was $80,76 \%$. It mean the increase of point from pre-test to cycle II was $73,77 \%$.

In detail, the mean of the students' score and it percentage could be seen in the table below:

Table 4.4 The mean Score of All Test

\begin{tabular}{|l|l|l|}
\hline Kinds of Test & The Average & The Percentage \\
\hline Pre-test & 53,19 & $7,69 \%$ \\
\hline Formative Cycle I & 60,03 & $15,38 \%$ \\
\hline Post-test Cycle II & 76 & $80,76 \%$ \\
\hline
\end{tabular}

Form the table above, mean of the students' score of pre-test was 53,19 mean of the students' score of formative test cycle I was 60,03 , mean of the students score of post-test cycle II was 76. So, think pair share can be improved students' reading comprehension can be seen from the percentage. The percentage of cycle I and cycle II increasing 65,38\% then the writer did the research from pre-test to post-test cycle II, the students improved the students' reading comprehension. The percentage of pre-test to post-test cycle II increasing 73,07\%. From the result can be seen that think pair share can be improved the students' reading comprehension in narrative text.

\section{Discussion}

Think pair share technique was applied to improve students' reading comprehension to ninth grade students of Junior High School Era Ibang Medan Class IX. When the researcher applied the think pair share, the students became focus. The researcher analyzed that some of the students did not pay attention to teacher they more enjoyed to told with his friends. When the researcher did the pre-test, the students' scores were low just 2 students of 26 students passed KKM. After applying think pair share technique, the students' mean score in formative

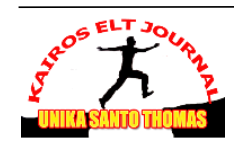


cycle I improved. When the researcher did the cycle II, they paid more attention and the result can be seen that students' score improved 21 students passed KKM. So from the result it can be concluded that think pair share technique can improve students' reading comprehension.

However, the researcher found some problems. There were many students in that class who made noisy when the researcher wanted approach other students. The researcher got difficulty to manage some of them who made noisy. Because they so naughty. And some of them looked want to gave them some attention, or found attention. It was because they were still young. They always want to be noticed. And also it because of the background of their knowledge and the students in that class were not smart. That's why the researcher gave them motivation to study hard, did not lazy to learn when the teacher explained the material in class, try to focus to heard what the teacher explained. Always spirit and never give up. So, if they want to continue their study they did not made a wrong choices they can chose what they want became one day and also can help their parents and have a bright future for her family and for their self of course.

\section{CONCLUSIONS}

Based on data analysis and discussion, it can be concluded that

1. The writer found that the think pair share can improved the students' reading comprehension.

In cycle I, the researcher started the treatment teaching reading comprehension by using think pair share technique. The researcher asked them to apply the technique on the text after giving the examples about think pair share. The researcher also explained think pair share in the process of comprehending of a text in reading activities. The researcher invited the students to get involved in the reading activities so that they understand more how to solve their reading problems. The researcher found that the think pair share improved the students reading comprehension.

In Cycle II, the writer found the students improvement. The researcher explained about think pair share and asked question how far they knew it after they learning in cycle 1 . The researcher shared the students into 5 groups so that they can learn with their friends in the group. The researcher found that the think pair share can improve the students reading comprehension. The technique also improved the students creativity and vocabulary mastery.

From the result of the students scores above, it is concluded that their mean score improved. It is seen from the scores of post-test cycle I to post-test cycle II. In pre-test, the students mean score was 53,19 then students mean score in formative cycle I was 60,03 increasing point was 6,84 points, and in post-test cycle II was 76 . The increasing point from pre-test to cycle II was 15,97 points.

2, The think pair share can improve students reading comprehension on narrative text through it. They can identify the main ideas of the text. The technique also improved the students creativity. They can read text effectively and this technique makes funny and interesting to increase their capabilities. Based on the result of the study, it is found that the think pair share technique is one of many reading techniques to improve the students skills of reading. If they can improve their reading skills, they will be able to understand a text they are reading and find main idea in the text easily. This study has proven that the students reading comprehension were improved after the writer implemented some actions in the classroom.

Based on the conclusions above, there are some suggestions that will be directed to : 
KAIROS ELT JOURNAL, Vol. 1, No. 3, December 2017

Copyright@2017, ISSN: 2580-4278

1. The English teachers, to use reading techniques in the classroom to make the process of reading learning more effective and enjoyable. This technique can help the students to comprehend a text easily and effectively.

2. The students need more practices to improve their reading skills so that they can comprehend English text easily. When they find difficulties, they can share with their friends or teacher freely. They should also motivate themselves to study hard so they can reach better achievement. The think pair share is the way to improve the reading skills.

3. The other researcher to learn and to find more variation of actions and use the think pair share to improve students reading comprehension, to conduct this study to other schools in Indonesia who having this problems.

\section{BIBLIOGRAPHY}

Anderson, Neil. 2003. “What is reading?”. In Nunan, D. ( $3^{\text {rd }}$ Ed). Practical English Language Teaching. New York: McGraw-Hill.

Arrends, R.I. 2007. Learning to Teach $7^{\text {th }}$ Edition. New York: The McGraw. Hill Companies, inc. (351).

Arrends, R.I. 2009. Learning to Teach $9^{\text {th }}$ Edition. New York: The McGraw.Hill Companies, inc.

Broughton,G. 2003. Teaching by English as a Foreign Language. New York: Routledge.

Burns, A. 2010. Doing Action Research in English Language Teaching: A Guide for Practioners. Sydney: Macquaric University. (80)

Carnine, Douglas, et al, 1990. Direct Instruction, Colombus: Merril Publishing Company.

Fauziyati, R. 2013. The Effect of Using Think Pair Share Technique on the Eight Grade Students Reading Comprehension Achievement. International Journal of Teaching Education.

Grabe, William and Frederika L. Stoller. 2002. Teaching and Researching Reading. London: Pearson Education.

Kagan, S. 2009. Kagan Cooperative Learning. Kagan Publishing.

Koshy, Valsa. 2010. Action Research for Improving Educational Practice. Los Angeles: Sage Publications.

Jollife, W. 2007. Cooperative Learning in the Classroom Putting into Practice. London: SAGE Publications Company.

Ledlow, S. 2001. Using Think Pair Share in the College Classroom. New York: Center for Learning and Teaching Excellence.

Metteal, Gwynn. 2001. The What, Why and How of Classroom Action Reserach. Journal of Scholarship in Teaching and Learning (JoSoTL).

Neo, Ernest. 2005. Narrative for 'O' level. Malaysia: Longman. 
KAIROS ELT JOURNAL, Vol. 1, No. 3, December 2017

Copyright $\odot 2017$, ISSN: 2580-4278

Sugiarto, Dino. 2014. The Implementation of Think Pair Share Model to Improve Students' Ability in Reading Narrative Texts. International journal of English and Education.

Wahyuni, Sri. 2014. Using Think Pair Share Method to Improve the Reading Skill on Narrative Text of the Students. Journal of Using Think Pair Share Method. 